\title{
Ovarian Impairment in Fish, Channa punctata (Bloch) on Exposure to Mercuric Chloride, Caldan 50 SP and their Mixture
}

\author{
Shalini Rai ${ }^{1}$, Kamlesh K. Yadav ${ }^{2}$ and Sunil P. Trivedi ${ }^{3 *}$ \\ 'BDSP Mahila Degree College, Bhadehara Khochawa, Varanasi, Uttar Pradesh, India; raishalini_rai@rediffmail.com \\ ${ }^{2}$ Government Degree College, Bakkha Khera, Unnao - 209801, Uttar Pradesh, India; drkkyadav8@gmail.com \\ 3Environmental Toxicology and Bioremediation Laboratory, Department of Zoology, \\ University of Lucknow, Lucknow - 226007, Uttar Pradesh, India; \\ sat060523@gmail.com
}

\begin{abstract}
Extensive and arbitrary use of pesticides in agriculture and heavy metals in industries as catalysts have caused impending hazards to aquatic organisms. Fishes occupying higher positions in trophic level of the aquatic food chain suffers the most due to the industrial discharge and agrochemicals. Reproductive system is one of the most important systems which gets affected to a great extent and in turn affect the reproductive processes and fecundity of animals. Present investigation deals with both synergistic and individual effects of mercuric chloride (MC), an industrial effluent and Caldan 50SP (C50SP), on the histological profile of ovary of a fresh water food fish Channa punctata (Bloch) after 15, 30 and 60 days of exposure periods. Notable histopathological findings include deshaped ovum, ruptured ovarian epithelium, stromal hemorrhage and vacuolization in the ovaries. The extent of ovarian damage was exposure dependent under the impact of individual toxicants, however their synergistic effects pronounced more severe damage even when individual toxicants were in lesser concentration and exposure time was also comparatively less. The results obtained will be helpful to understand the combined effect of MC and C50SP on the ovary of fishes and these findings are quite suggestive of reproductive impairments leading to delayed ovarian maturity and adversely affecting process of ovulation and thus, fish production.
\end{abstract}

Keywords: Caldan 50SP (C50SP), Fish, Gonads, Mercuric Chloride $\left(\mathrm{HgCl}_{2}\right)$, Synergistic Effect

\section{Introduction}

Water pollution has become inevitable owing to over-industrialization, rapid civilization, green revolution and over population. Indiscriminate and extensive use of pesticides in agriculture and heavy metals in industries as catalysts and electrolytes indirectly cause potential hazards to aquatic animals $\frac{1,2}{2}$. The agricultural run-off and water from the fields that drains into the rivers containing pesticides and industrial effluents having heavy metals are now recognized as environmental pollutants. They have considerable toxic effects on aquatic fauna including fishes. Among metals, one of the ubiquitous water pollutants is mercury. Environmental contamination due to mercury is wide spread as a result of industrial activities. It is used as a fungicide in agriculture, in the manufacture of chlorine and sodium hydroxide, as a slime control agent in the pulp and paper industry, in the production of plastics and electrical apparatus and in mining and smelting operations ${ }^{3}$. Its toxicity was known as early as $16^{\text {th }}$ century $y^{4}$. It has also been found genotoxic. It induces formation of micronuclei and also causes chromosomal aberrations in fish Channa puctata ${ }^{5-7}$.

Although pesticides play a crucial role in modern agriculture but they fall among the hazardous chemicals released by man into the environment ${ }^{8-10}$. Ideally a pesticide should be lethal to the targeted pests, but not to non-target species, including man. Unfortunately, this is not so, the controversy of use and abuse of pesticides has surfaced at large scale. The rampant use of these chemicals, under the adage, "if little is good, a lot more will be better" has played havoc with humans and other life

*Author for correspondence 
forms. C50SP is one of the most frequently used pesticides to control insect pests in agricultural fields. It is an insecticide which is derived from the naturally occurring insecticidal substance isolated from the marine segmented worms Lumbrinereis heteropoda and Lumbrinereis brevicirra. It is used against a relatively broad spectrum of insects, e.g. Lepidoptera, Coleoptera, Diptera and Hemiptera. Synthetic pyrethroid, devicyprin (cypermethrin 25\%) induced gonadal impairment in a freshwater food fish, Channa punctatus(Bloch) have been reported by ${ }^{11}$.

Multichemical exposure is the rule rather than an exception. Chemical mixtures in the environment can be and generally are complex, consisting of parent compounds, reaction or transformation products along with other residues. Exposure of biota to combinations of pollutants may sometimes result in unexpected consequences, i.e. significantly lower or greater toxic response than a simple summation of the response induced by the mixture components taken individually. Mixture of pollutants in the environment can influence the toxicity of each other which could be altogether different and more pronounced from their individual toxicological effects ${ }^{12,13}$. This is called synergistic effect or synergy. Ammonia combines with copper to form very stable complex cations of cuprammonium $\left[\mathrm{Cu}\left(\mathrm{NH}_{3}\right)_{4}\right]^{2+}$ and it enhances the copper toxicity. James and Sampath, (1995) reported that the individual effect of copper is more toxic than ammonia and two of the combinations are more toxic than the individual effect of copper and ammonia ${ }^{14}$.

Trivedi and Rai (2007) have reported the impact of mercuric chloride, Caldan 50SP and their mixture on histological architecture of the kidney of Channa punctata (Bloch) ${ }^{15}$. They also investigated the effect of sub-lethal concentrations of mercuric chloride, Caldan 50SP, both individually as well as in combination by exposing the fish Channa punctata for 15, 30 and 60 days, on the hepatocellular profile of the fish. They reported several histopathological changes viz. inflammation, swelling, necrosis, vacuolization and hypertrophy in hepatocytes in the liver of fish Channa punctata $\frac{13,16}{}$. Potential ecotoxicological hazard of mercuric chloride, Caldan 50SP and their synergistic effect, on gills of a fresh water fish, Channa punctata as a test animal has also been reported Rai et al., $2018^{17}$. In present study, an effort has been made to evaluate the toxicity of Mercuric Chloride and Caldan 50SP, individually and in combination (synergistic effect), in the fish model, Channa punctata .

\section{Materials and Methods}

In the present investigation adult and healthy specimens of Channa punctata measuring $13.90 \pm 0.394 \mathrm{~cm}$ in length and $29.80 \pm 0.789$ grams in weight were collected from local fresh water resources of Lucknow and brought to laboratory in wide mouthed plastic buckets, in natural water, avoiding stress and mechanical injuries as far as possible. Fish were transferred to large glass aquaria $(100 \times 40 \times 40 \mathrm{~cm})$ and thoroughly washed with tap water thrice and were then given prophylactic treatment to remove external infections due to bacteria, protozoa, monogenetic trematodes and arthropods. For this purpose, a wash of $1 \mathrm{mgL}^{-1}$ solution of $\mathrm{KMnO}_{4}$ for 1 hour was given to fish. Fishes were acclimatized for 10 days containing aged for proper gaseous exchange, aerators were used tap water.. During this period fish were fed with minced goat liver and artificial fish food Tokyo. Every effort was made to maintain optimal condition during acclimatization.

$96 \mathrm{~h} \mathrm{LC}_{50}$ of the test chemicals calculated by "Trimmed Spearman-Karber method"18. Ten fishes were exposed to sublethal concentration of Mercuric Chloride $\left(1 / 10^{\text {th }} 96 \mathrm{hr} . \mathrm{LC}_{50}\right.$; $0.081 \mathrm{mg} / \mathrm{l})$, Caldan $50 \mathrm{SP}\left(1 / 10^{\text {th }}\right.$ of $\left.96 \mathrm{hr} . \mathrm{LC}_{50} ; 0.153 \mathrm{mg} / \mathrm{l}\right)$ and $1 / 20^{\text {th }}$ of each of their concentration together (synergistic effect) for 15, 30 and 60 days of exposure periods respectively along with a parallel control experiment. Physico-chemical characteristics of water were analyzed at the commencement and termination of each experiment, using standard procedures ${ }^{19}$.

After the termination of each experiment, fishes were dissected in Ringer's solution. Ovaries were then taken out and processed for microtomy. Significant findings were recorded by NIKON-HFX-DX trinocular microscope and NIKONFX-35-DX camera with automatic time recorder. Changes in exposed sections of ovaries were compared with that of control sections.

\section{Results}

The histoanatomy of ovaries of fish exposed to sublethal concentration of Mercuric Chloride $\left(1 / 10^{\text {th }} 96 \mathrm{hr} . \mathrm{LC}_{50} ; 0.081\right.$ $\mathrm{mg} / \mathrm{l})$, Caldan 50SP $\left(1 / 10^{\text {th }}\right.$ of $\left.96 \mathrm{hr} . \mathrm{LC}_{50} ; 0.153 \mathrm{mg} / \mathrm{l}\right)$ and $1 / 20^{\text {th }}$ of each of their concentration together (synergistic effect) for 15, 30 and 60 days of exposure periods showed varied histopathological findings (Table 1). 
Table 1. Individual and synergistic effects of C50SP and Mercuric Chloride on the ovary of Channa punctata

\begin{tabular}{|c|c|c|c|c|}
\hline \multirow{2}{*}{$\begin{array}{l}\text { Exposure } \\
\text { periods }\end{array}$} & \multirow{2}{*}{$\begin{array}{l}\text { Histology of Normal Ovary } \\
\text { (Control) }\end{array}$} & \multicolumn{3}{|c|}{ Histology of Ovary Exposed to } \\
\hline & & MC & C50SP & $\mathrm{MC}+\mathrm{C} 50 \mathrm{SP}$ \\
\hline 15 & \multirow{3}{*}{$\begin{array}{l}\text { The wall of ovary consists of } \\
3 \text { layers, peritoneum, tunica } \\
\text { albuginea and germinal } \\
\text { epithelium. The germ cells } \\
\text { originate from germinal } \\
\text { epithelium. A ripe ovum is } \\
\text { large in size, yellowish in color } \\
\text { and translucent. It is full of } \\
\text { yolk globules, vesicles and } \\
\text { nucleus. (Figure 1) }\end{array}$} & $\begin{array}{l}\text { Yolk vesicles arranged at the } \\
\text { periphery of oocytes, stromal } \\
\text { haemorrhage and vacuoles more } \\
\text { prominent. (Figure 2) }\end{array}$ & $\begin{array}{l}\text { Yolk vesicles and globules } \\
\text { arranged in the periphery of } \\
\text { ovum and vacuolization in } \\
\text { cytoplasm. (Figure 4) }\end{array}$ & $\begin{array}{l}\text { Necrotic and degenerative } \\
\text { ovum along with stromal } \\
\text { haemorrhage. Ovum } \\
\text { swells with large sized } \\
\text { yolk vesicles. (Figure 6) }\end{array}$ \\
\hline 30 & & $\begin{array}{l}\text { Heavy stromal haemorrhage, } \\
\text { necrosis in ovigerous lamellae and } \\
\text { oocyte swelling. }\end{array}$ & $\begin{array}{l}\text { Rupturing of ovum, } \\
\text { narrowing of ovum lumen, } \\
\text { degeneration of ovarian } \\
\text { epithelium. }\end{array}$ & $\begin{array}{l}\text { Stromal haemorrhage } \\
\text { and ruptured follicular } \\
\text { epithelium. }\end{array}$ \\
\hline 60 & & $\begin{array}{l}\text { Disruption of ovarian follicle, } \\
\text { reduction in number of } \\
\text { mature ovum and } 2^{0} \text { oocytes, } \\
\text { degeneration of follicles and } \\
\text { follicular epithelial cells, } \\
\text { hypertrophy and hyperplasia. } \\
\text { (Figure 3) }\end{array}$ & $\begin{array}{l}\text { Vacuolization in cytoplasm, } \\
\text { deshaped ovum with } \\
\text { mild necrosis and stromal } \\
\text { haemorrhage. (Figure 5) }\end{array}$ & $\begin{array}{l}\text { Degeneration of ovum, } \\
\text { severely damaged } \\
\text { follicular epithelium and } \\
\text { distorted architecture of } \\
\text { ovaries. (Figure 7) }\end{array}$ \\
\hline
\end{tabular}

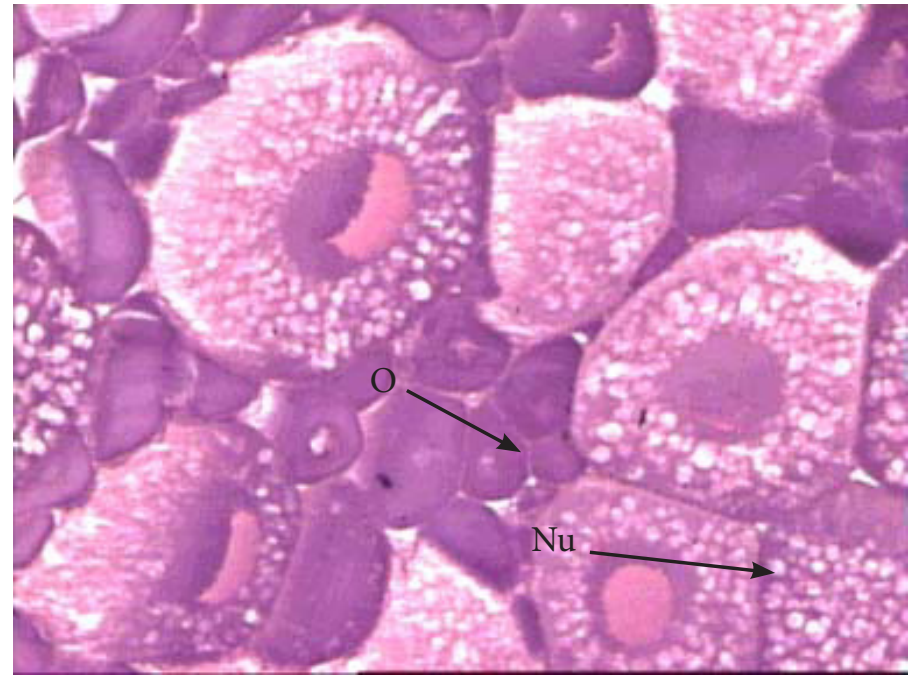

Figure 1. Section of the ovary of C. punctata from control showing normal Oocytes $(\mathrm{O})$ and nucleus $(\mathrm{Nu}),(\mathrm{H}$ and $\mathrm{E} \times 100)$.

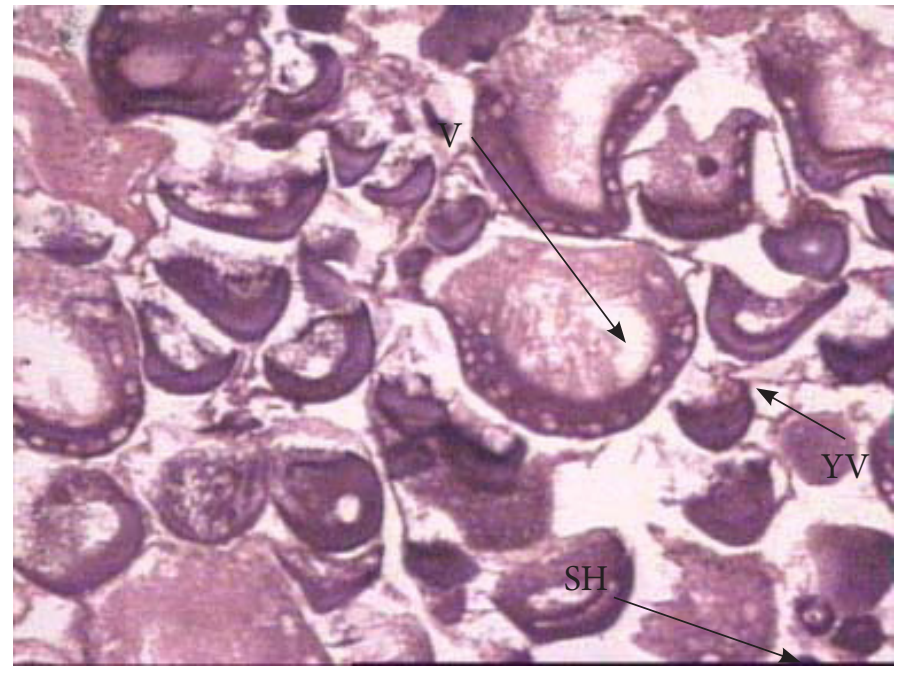

Figure 2. Section of ovary of C. punctata exposed to $96 \mathrm{~h} \mathrm{LC}_{50}$ 1/10 of Mercuric Chloride for 15 days showing Yolk Vesicles $(\mathrm{YV})$ at the periphery of Oocytes, Vacuolization (V) and Stromal Haemorrhage $(\mathrm{SH}),(\mathrm{H}$ and $\mathrm{E} \times 100)$. 


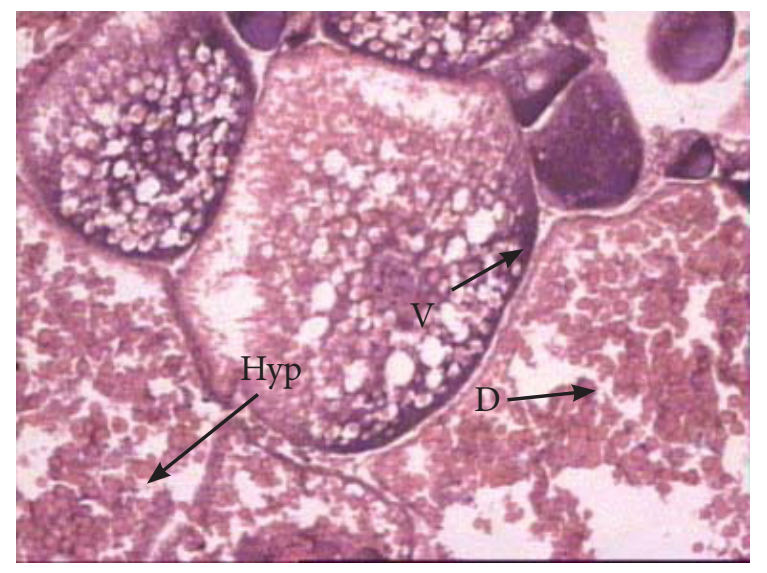

Figure 3. Section of ovary of C. punctata exposed to $96 \mathrm{~h}$ LC $_{50} 1 / 10$ of Mercuric Chloride for 60 days showing Oocytes of abnormal size having large number of Vacuoles $(\mathrm{V})$, degeneration of follicles (D) and hyperplasia (Hyp), (H and E x 100).

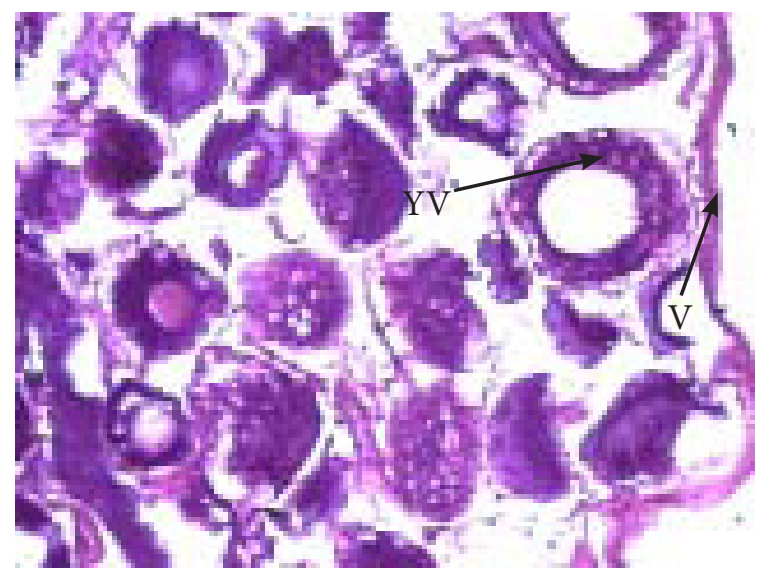

Figure 4. Section of ovary of C. punctata exposed to $96 \mathrm{~h} \mathrm{LC}_{50}$ 1/10 of Caldan 50SP for 15 days showing vacuolization (V) and Yolk Vesicles (YV) arranged at the periphery of the ovum (H and $\mathrm{E} \times 100)$.

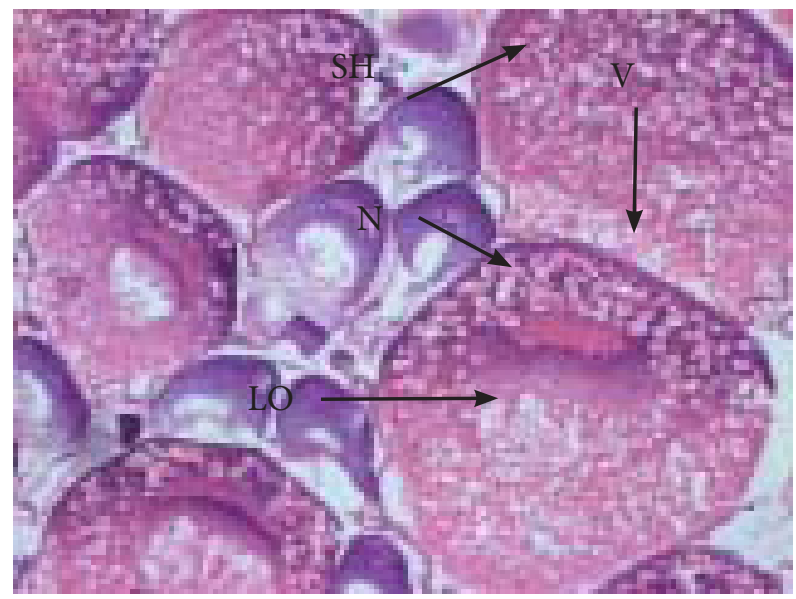

Figure 5. Section of ovary of C. punctata exposed to $96 \mathrm{~h}$ $\mathrm{LC}_{50} 1 / 10$ of Caldan $50 \mathrm{SP}$ for 60 days showing vacuolization in cytoplasm (V), almost deshaped large ovum (LO), Necrosis (N) and Stromal Haemorrhage $(\mathrm{SH}),(\mathrm{H}$ and $\mathrm{E} \times 100)$.

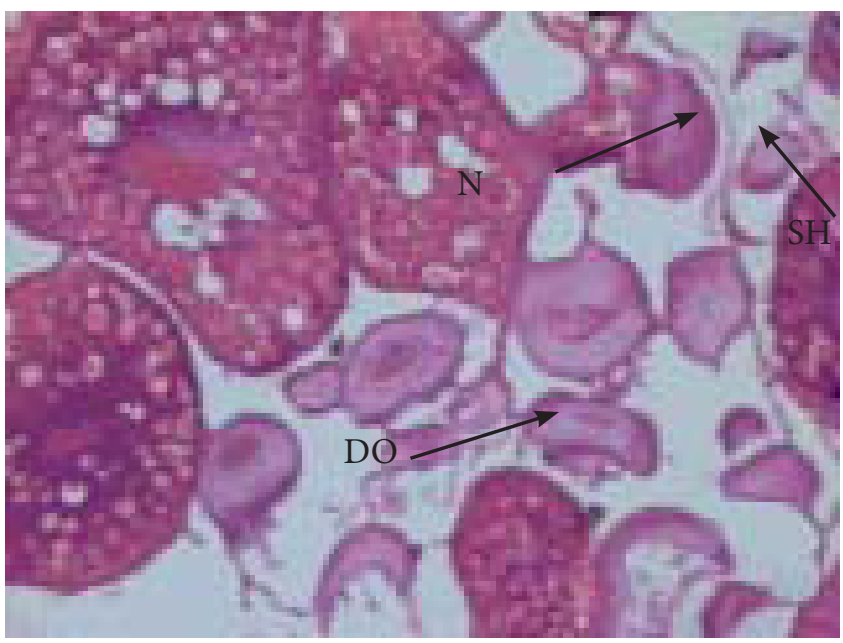

Figure 6. Section of ovary of C. punctata exposed to mixture of Mercuric Chloride and Caldan 50SP ( $96 \mathrm{~h} \mathrm{LC}_{50} \times 1 / 20$ of each) for 15 days showing Necrosis $(\mathrm{N})$ and Degenerative Ovum (DO) along with Stromal Haemorrahage $(\mathrm{SH}),(\mathrm{H}$ and $\mathrm{E} \times 100)$.

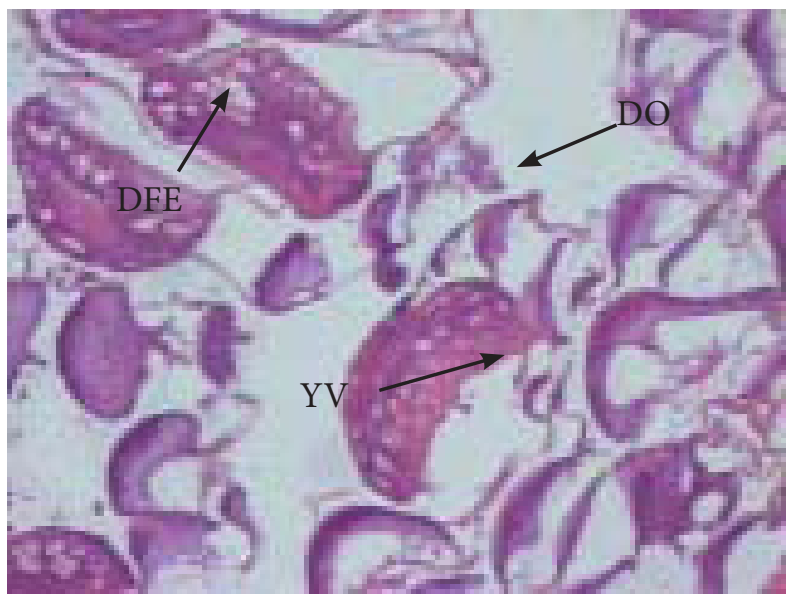

Figure 7. Section of ovary of C. punctata exposed to mixture of Mercuric Chloride and Caldan 50SP $\left(96 \mathrm{~h} \mathrm{LC}_{50} \times 1 / 20\right.$ of each) for 60 days showing Degenerating Ovum (DO), Yolk Vesicles (YV) and Damaged Follicular Epithelium (DFE), $(\mathrm{H}$ and $\mathrm{E} \times 100)$.

\section{Discussion}

Fishes occupy the utmost position in the trophic level of aquatic ecosystem, thus suffer most due to the industrial discharge and pesticides which impinge in different systems. Reproductive system is one of the most important systems which to a great extent is affected by these toxicants. It is now evident that toxic substances such as heavy metals and pesticides introduced in the environment affect the reproductive processes and fecundity of animals $s^{20,21}$.

In the present investigation, fish $C$. punctate, exposed to sublethal concentration of Mercuric Chloride registered gross histopathological changes in their ovaries and the normal configuration of the ovary was almost lost. Degenerative 
changes in both ovary and testis with reduced gonadosomatic index on exposure to mercurial fungicide Emisan ( $\mathrm{MeEHgCl})$ in catfish Clarias batrachus was also reported by Das and Sengupta,199322. Almost similar changes were recorded by Shukla and Pandey (1984) in fish Colisa fasciatus exposed to $14.0 \mathrm{mg} / \mathrm{l}$ of arsenic for 15 and 30 days of exposure period ${ }^{23}$. They observed marked degenerative changes after 30 days of exposure period. These changes included prominent follicular spaces, reduction in the development of $2^{\text {nd }}$ and $3^{\text {rd }}$ stage of oocyte, reduced number and diameter of nucleoli and atretic follicles. Histopathological changes in the gonads of fishes after pesticide exposure has been reported by many workers ${ }^{24,25}$. The treatment of fresh water Indian cat fish Clarias batrachus (Linn.) with Butachlor 2 chloro-N-(2-6 diphenyl) acetamide at a dose of $1.5 \mu \mathrm{l} / \mathrm{L}$ for 5,10 and 15 days led to significant decline in the number of healthy follicles and increase in the number of atretic follicles leading to altered follicular kinetics ${ }^{26}$.

Exposure to C50SP also caused noticeable histopathological changes in the ovaries of $C$. punctata but the degree of changes was less pronounced as compared to Mercuric Chloride treated fish and the fish treated with mixture of toxicants. Similar changes were reported by Hazarika and Das (1998) in the air-breathing fish $\mathrm{H}$. fossilis (Bloch) on exposure to $\mathrm{BHC}^{27}$. They observed vacuolization in cytoplasm of germinal cells, partial disruption of ovarian follicles and reduction in number of matured ovum and secondary oocytes. In fishes, pesticides seem to retard gonadotropin secretions (Singh and Singh, 1981), thereby causing inhibition of gonadal growth. Zutshi (2005), observed appreciable reduction in size, with spermatids and sperms in degenerating condition and necrosis of interstitial cells after fenthion treatment in fish, Glossogobius giuris ${ }^{28,29}$. Zutshi and Murthy (2001) reported extensive cytotoxic damage in the testis of gobid fish Glossogobius giuris after fenthion exposure ${ }^{30}$. They observed that cytoplasm was reduced to granular material with fragmented endoplasmic reticulum and which was devoid of mitochondria and lipid droplets. The spermatozoa of treated fish showed atrophy in the head and tail region.

Exposure of fish to the mixture of toxicants (MC+C50SP) showed profound histopathological changes in the gonads as compared to the fish treated with single toxicant. Trivedi and Rai (2007) have reported the synergistic effect of Mercuric Chloride and Caldan 50SP on histological architecture of the kidney of Channa punctata (Bloch) $\frac{15}{15}$. They also investigated the effect of sub-lethal concentrations of mercuric chloride, Caldan 50SP, both individually as well as in combination by exposing the fish Channa punctata for 15, 30 and 60 days, on the hepatocellular profile of the fish. They reported several histopathological changes viz. inflammation, swelling, necrosis, vacuolization and hypertrophy in hepatocytes in the liver of fish Channa punctata ${ }^{16}$. Potential ecotoxicological hazard of mercuric chloride, Caldan 50SP and their synergistic effect, on gills of a fresh water fish, Channa punctata as a test animal has also been reported by Rai et al.,2018 ${ }^{17}$. Inadequate literature is available supporting such histopathological changes due to metal and pesticides mixture exposure to the fish and other animals. But it is quite suggestive that these alterations may lead to the suppression of ovarian activity resulting in the impairment of reproductive potential of the fish.

\section{Conclusion}

Present study concludes that metal and pesticide exposure alter the normal architecture of ovarian tissue of $C$. punctata. The toxicity of Mercuric Chloride and Caldan 50SP is dose and time dependent. Although the exact mechanism of such alterations may be yet to be known, it can be established that oxidative stress is one of the prime causes for such aforementioned histo-pathological insults in the fishes. Definitely, there is an urgent need for proper monitoring and regulation of concentration of pesticides and heavy metals and their residues in aquatic habitats not only to safeguard fish biodiversity but consumer's health as well.

\section{Acknowledgement}

The authors are thankful to the Head, Department of Zoology, University of Lucknow, Lucknow, Uttar Pradesh, India, for providing the necessary facilities to conduct the research work.

\section{References}

1. Dwivedi S, Kumar M, Trivedi SP. Mitigating potential of Melissa officinale against As 3+-induced cytotoxicity and transcriptional alterations of Hsp70 and Hsp27 in fish, Channa punctatus (Bloch). Environmental Monitoring and Assessment. 2017; 189(7):306. PMid: 28573351 https://doi.org/10.1007/s10661-017-6002-7

2. Awasthi Y, Ratn A, Prasad R, Kumar M, Trivedi SP. An in vivo analysis of $\mathrm{Cr} 6+$ induced biochemical, genotoxicological and transcriptional profiling of genes related to oxidative stress, DNA damage and apoptosis in liver of fish, Channa punctatus (Bloch, 1793). Aquatic Toxicology. 2018; 200:158-67. PMid: 29753883. https://doi.org/10.1016/j.aquatox.2018.05.001

3. Eisler R: Trace metal concentrations in marine organisms. Pergamon Press; New York. 1987. p. 687.

4. Ramalingam U, Paneerdoss S, Girija M, IIango S. Mercuric Chloride induced changes in the histology of the testis and serum testosterone in adult albino rats. Pollut Res. 2001; 20:439-42. 
5. Yadav KK, Trivedi SP. Evaluation of genotoxic potential of Chromium (VI) in Channa punctata fish in terms of chromosomal aberrations. Asian Pacific J Cancer Prev. 2006; 7:472-6. PMid: 17059348.

6. Yadav KK, Trivedi SP. Sublethal exposure to heavy metals induces micronuclei in fish, Channa punctata. Chemosphere. 2009; 77:1495-500. PMid: 19880156. https://doi.org/10.1016/j. chemosphere.2009.10.022

7. Yadav KK, Trivedi SP. Chromosomal aberrations in a fish, Channa punctata after in vivo exposure to three heavy metals. Mutation Research. 2009; 678:7-12. PMid: 19545645. https://doi.org/10.1016/j.mrgentox.2009.05.021

8. Giri AN, Srivastava DK, Trivedi SP. Insecticide basathrin induced histo anatomical insult of ovarian tissue of Indian catfish, Heteropneustes fossilis. Biological Memoirs. 2000; 26:20-4.

9. Pandey AK, Trivedi SP. Genotoxicity assessment of DNA damage by single cell gel electrophoresis (SCGE)/comet assay in fish. National Academy Science Letters. 2009; 32(9/10):257-61.

10. Ratn A, Awasthi Y, Kumar M, Singh SK, Tripathi R, Trivedi SP. Phorate induced oxidative stress, DNA damage and differential expression of p53, apaf-1 and cat genes in fish, Channa punctatus (Bloch, 1793). Chemosphere. 2017; 182:382-91. PMid: 28511133. https://doi.org/10.1016/j.chemosphere.2017.05.008

11. Srivastava RK, Yadav KK, Trivedi SP. Devicyprin induced gonadal impairment in a freshwater food fish, Channa punctatus (Bloch). J Environ Biol. 2008; 29(2):187-91. PMid: 18831372.

12. James R, Sampath K, Sivakumar V, Mamniramoorthy S. Individual and combined effects of heavy metals on survival and biochemistry of Oreochromis mossambicus. Ind J Fish. 1991; 38:49-54.

13. James R, Sampath K, Punithavathi PK. Effect of metal mixtures on activity of two respiratory enzymes and their recovery in Oreochromis mossambicus. Ind J Expt Biol. 1992; 30:496-9. PMid: 1506030.

14. James R, Sampath K. Sublethal effects of mixtures of copper and ammonia on selected biochemical and physiological parameters in the catfish Heteropneustes fossilis (Bloch). Bull Environ Contam Toxicol. 1995; 55(2):187-94. PMid: 7579922. https://doi. org/10.1007/BF00203008

15. Trivedi SP, Rai S. Impact of Mercuric Chloride ( $\mathrm{HgCl} \sim 2)$, Caldan 50SP (C50SP) and their mixture on histological architecture of the kidney of Channa punctata (Bloch). Journal of Advanced Zoology. 2007; 28(2):72.

16. Trivedi SP, Rai S. Hepatocellular deformities induced by Mercuric Chloride and Caldan 50SP in a fresh water teleost, Channa punctata. J Appl Biosci. 2008; 34(1):74-8.
17. Rai S, Yadav KK, Trivedi SP. Impact of chronic mercury and Caldan 50SP poisoning on the gills of fresh water fish, Channa punctata (Bloch). Res Environ Life Sci. 2018; 11(1):26-9.

18. APhA AW. WEF (American Public Health Association, American Water Works Association and Water Environment Federation). 1998. Standard methods for the examination of water and wastewater. 1998. p. 19.

19. Hamilton MA, Russo RC, Thurston RV. Trimmed spearmankarber method for estimating median lethal concentrations in toxicity bioassays. Environ Sci Technol. 1977; 11(7):714-9. https://doi.org/10.1021/es60130a004

20. Rajkumar R, Padmanabhan KG, Balasubramanian NK. Effect of sewage pollution on reproduction in Lebistes reticulus (Peters). Comp Physiol Ecol. 1984; 9:9-12.

21. Patil HS, Saidpur SK. Effect of pollution on reproductive cycles. Reproductive Cycles of Indian Vertebrates. 1989. p. 409-26.

22. Das RC, Sengupta B. Toxicological effect of a mercurial fungicide on the gonadal development of the catfish Clarias batrachus (Linnaeus). Veterinarski Arhiv. 1993; 63(1):19-29.

23. Shukla JP, Pandy K. Impaired ovarian functions in arsenic treated fresh water fish, Colisa fasciatus (bl and sch.). Toxicol Left. 1984; 20:1-3. https://doi.org/10.1016/0378-4274(84)90175-9

24. Pandey GC, Neraliya S. Impact of carbofuran on freshwater catfish H. fossilis (Bloch). Himalayan J Environ Zoo. 1998; 12:249-54.

25. Ramachandran MM. Malathion induced changes in the ovary of freshwater fish, Glossogobius giuris (Ham). Poll Res. 2000; 1(1):15-36.

26. Verma P, Chand GB. Butachlor induced oxidative and hormonal imbalance correlated with ovarian anomalies in fresh water indian cat fish Clarias batrachus (Linn.): SEM study. World J Pharma Res. 2015; 4(8):2327-40.

27. Hazarika R, Das M. Toxicological impact of BHC on the airbreathing catfish, Heteropneustes fossilis (Bloch). Bull Environ Contam Toxicol. 1998; 60:16-21. PMid: 9484551. https://doi. org/10.1007/s001289900585

28. Singh H, Singh TP. Effect of parathion and aldrin on survival ovarian 32p uptake and gonadotrophic potency in a fresh water catfish, Heteropneustes fossilis, (Bloch). Endocrinologie. 1981; 77:177.

29. Zutshi B. Ultrastructural studies on the effect of fenthion on pituitary (GTH cells) and testis of Glossogobius giuris (Ham) during breeding phase. J Environ Biol. 2005; 26(1):31-6. PMid: 16114458.

30. Zutshi B, Murthy PS. Ultrastructural changes in testis of gobid fish Glossogobius giuris (Ham) induced by fenthion. Indian J of Exp Biol. 2001; 39:170-3. PMid: 11480215. 